
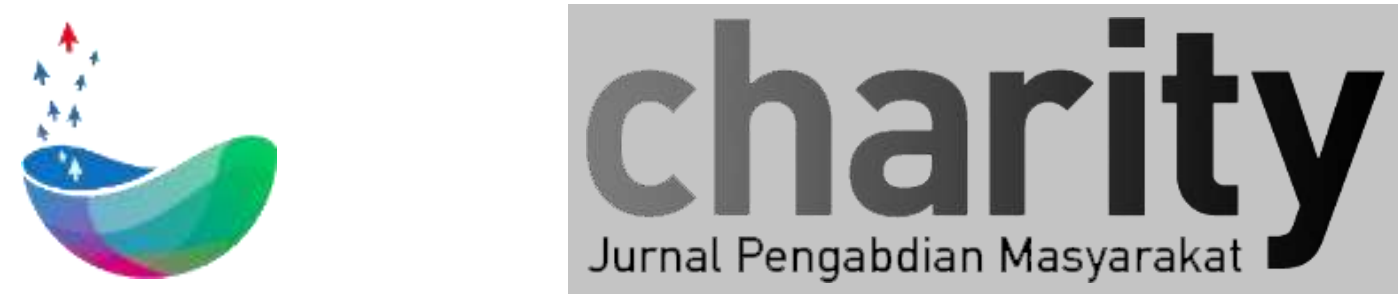

\title{
IMPLEMENTASI ALAT PENGUPAS DAN PENYARING KULIT ARI KACANG KEDELAI UNTUK MENINGKATKAN KAPASITAS PRODUKSI TEMPE CV. MITRA PANGAN SEJAHTERA, BANDUNG.
}

Agus Kusnayat ${ }^{1, * \#}$, Erna Febriyanti ${ }^{1 \#}$, Mohammad Yasin Abdul Hafidh ${ }^{1}$, Shinta Yulia ${ }^{2}$, Anisa Herdiani ${ }^{2}$, Indra Lukmana Sardi $^{2}$, Sri Martini ${ }^{1}$.

\footnotetext{
${ }^{1}$ Fakultas Rekayasa Industri, Universitas Telkom, Bandung

${ }^{2}$ Fakultas Informatika, Universitas Telkom, Bandung

* guskus@telkomuniversity.ac.id

\#Kedua penulis memiliki kontribusi yang sama terhadap manuskrip.
}

\section{INFO ARTIKEL}

Diterima 09 Juli 2019

Direvisi 16 Juli 2019

Disetujui 30 Agustus 2019

Tersedia Online 09 September 2019

\begin{abstract}
ABSTRAK
CV. Mitra Pangan Sejahtera merupakan usaha mikro kecil dan menengah (UMKM) di Karang Pamulang, Mandalajati, Kota Bandung, Jawa Barat yang bergerak dibidang produksi tempe. Saat ini CV. Mitra Pangan Sejahtera berharap untuk bisa mengolah 1 ton kedelai setiap harinya guna memenuhi kebutuhan konsumen. Namun, dalam proses produksi tempe ada beberapa proses yang memakan waktu. Salah satunya pada proses pemisahan kulit ari dari kacang kedelai. Proses pemisahan kulit dan kacang kedelai yang dilakukan selama ini adalah dengan pengadukan dan penyaringan secara manual menggunakan tangan dan bantuan ayakan bambu sederhana. Cara ini hanya efektif untuk jumlah yang kecil, yaitu sekitar 4 kuintal/hari. Untuk meningkatkan kemampuan produksi tempe, proses pemisahan tersebut harus dikembangkan. Dengan adanya mesin pengupas kulit ari maka tidak banyak tenaga yang diperlukan dan proses pemisahan kulit dari kacangnya dapat dilakukan lebih cepat sehingga meningkatkan produktifitas dan efisiensi.
\end{abstract}

Keyword: Alat pemisah, penyaring, kulit ari kacang kedelai, tempe, CV. Mitra Pangan Sejahtera.

\author{
Korespondensi: \\ Direktorat Penelitian dan Pengabdian Masyarakat, Universitas Telkom \\ Jl. Telekomunikasi No. 1, Terusan Buah Batu, Bandung, 40257 \\ Indonesia \\ E-mail : charity@telkomuniversity.ac.id \\ ORCID ID: - \\ Penulis Pertama: Agus Kusnayat \\ https://doi.org/10.25124/charity.v2i1.2122
}

Paper_reg_number 2122 @ The Authors. Published by Directorate of Research and Community Service, Telkom University.

This is an open access article under the CC BY-NC 4.0 license (https://creativecommons.org/licenses/ by-nc/4.0/) 
Tempe merupakan sumber protein nabati yang sangat penting bagi masyarakat Indonesia. Pada tahun 2017, rata-rata konsumsi tempe per kapita seminggu di Indonesia adalah sebesar 147 gram [1]. Indonesia merupakan negara produsen tempe terbesar di dunia dan menjadi pasar kedelai terbesar di Asia. Sebanyak 50\% konsumsi kedelai Indonesia digunakan untuk produksi tempe, $40 \%$ untuk tahu, dan $10 \%$ dalam untuk produk lain seperti tauco dan kecap [2]. CV. Mitra Pangan Sejahtera merupakan usaha mikro kecil dan menengah (UMKM) di Karang Pamulang, Kota Bandung, Jawa Barat (Gambar 1) yang bergerak dibidang produksi tempe. CV. Mitra Pangan Sejahtera beroperasi sejak 2014 dan diharapkan dapat memenuhi kebutuhan tempe yang berkualitas, sehat dan bebas bahan pengawet.

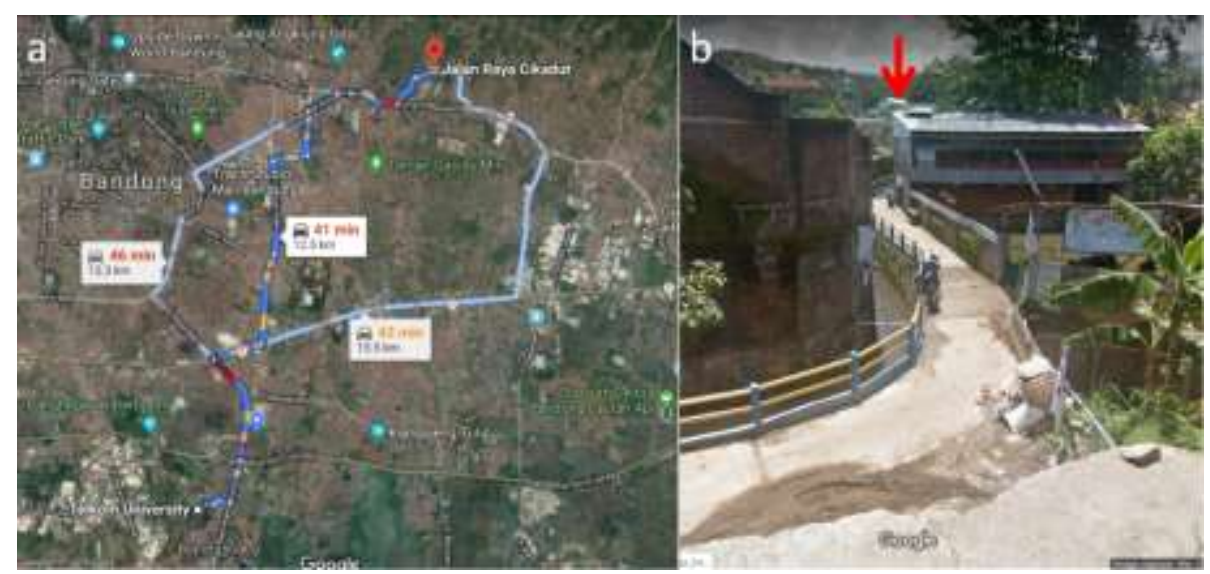

Gambar 1. (a) Peta arah lokasi mitra dari kampus Telkom University, (b) Lokasi CV. Mitra Pangan Sejahtera yang berada di belakang bangunan dua lantai (panah merah).

Gambar 2 merupakan diagram alir proses pembuatan tempe pada perusahaan CV. Mitra Pangan Sejahtera. Cara pengolahan tempe di tingkat perajin berbeda antara satu daerah dan daerah lain serta antara satu perajin dan perajin lainnya [3]. Secara umum, proses produksi tempe dibagi menjadi dua tahap utama, yaitu tahap kering dan tahap basah. Tahap kering terdiri dari penyortiran, peragian, dan pencetakan dan penyimpanan selama 15 jam. Sementara tahap basah terdiri perebusan, pemisahan kulit kedelai dari kacangnya, dan fermentasi. perebusan dapat membunuh bakteri-bakteri patogen yang ada pada kedelai. Pada proses perebusan, kedelai direbus didalam air mendidih selama 40-90 menit dengan komposisi 2L air/ kg kedelai dalam setiap proses perebusan. 


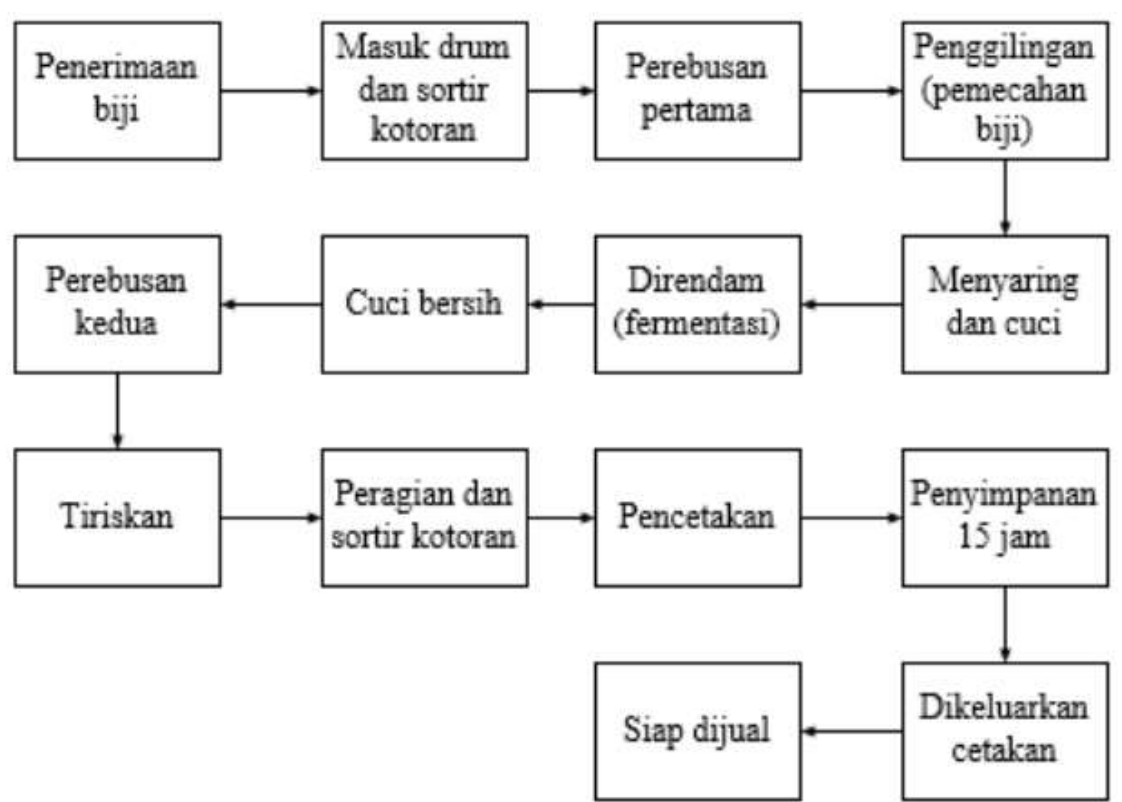

Gambar 2. Alur Produksi Tempe Mitra Pangan Sejahtera

Kemudian, kulit kacang kedelai dikupas dengan bantuan alat penggiling otomatis (Gambar 3a). Setelah itu kacang dan kulitnya dipindahkan untuk proses pencucian (Gambar 3b) dan penyaringan (Gambar 3c). Di CV. Mitra Pangan Sejahtera, proses penyaringan (kulit ari) menjadi salah satu proses penting karena pada proses ini dilakukan secara manual menggunakan anyaman bambu dengan cara menempatkan kedelai dan air dalam sebuah drum lalu air tersebut diputar dengan kecepatan putaran kurang lebih 50 rpm menggunakan ayakan. Setelah itu operator mengaduk drum tersebut, lalu menangkap kulit yang ada di tengah permukaan air dan mengumpulkannya dengan ayakan.

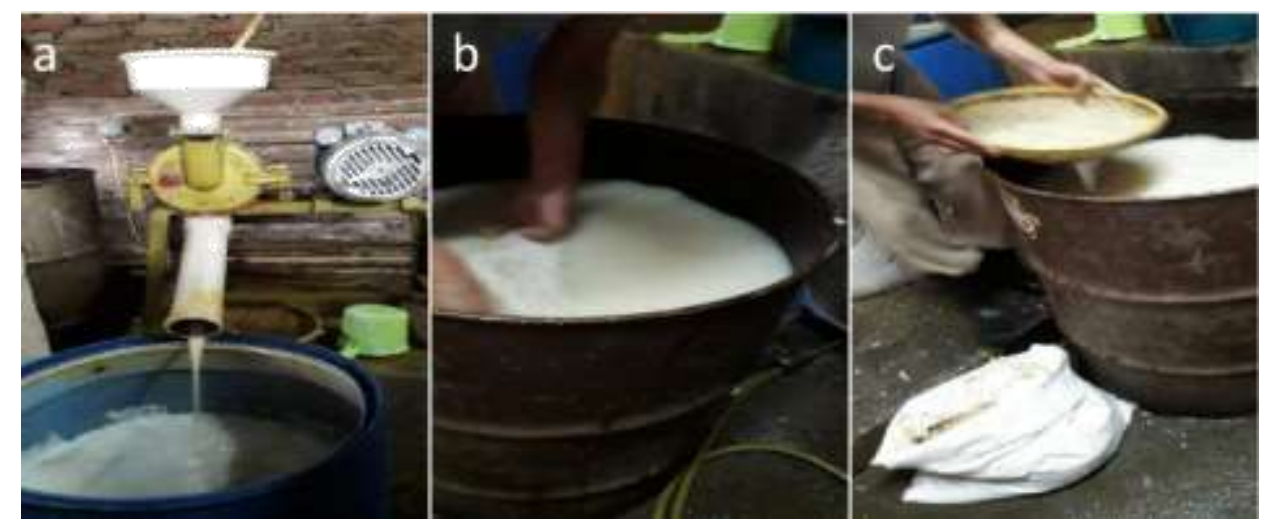

Gambar 3. (a) Proses pemecahan kulit ari kedelai,(b) Proses pengadukan manual kacang kedelai hasil penggilingan untuk pembersihan kulit ari, (c) Proses pemisahan kulit kacang kedelai.

\section{PERMASALAHAN MITRA}

Saat ini CV. Mitra Pangan Sejahtera berharap untuk bisa mengolah 1 ton kedelai setiap harinya untuk memenuhi kebutuhan konsumen. Namun, dalam proses produksi tempe, beberapa proses yang memakan waktu adalah pada proses penyaringan (kulit ari), proses direndam 
(fermentasi) dan proses penyimpanan agar jamur tempe tumbuh dan saling merekat. Proses pemisahan kulit ari kedelai merupakan proses yang sangat memakan waktu dan terjadi setelah proses penggilingan (pemecah biji). Proses ini dilakukan oleh seorang pekerja yang bekerja sekitar 20 menit dalam satu kali penyaringan (kurang lebih $25 \mathrm{~kg}$ kedelai). Proses ini menggunakan 2 buah komponen alat bantu produksi, yaitu wadah untuk menampung kacang kedelai dan ayakan untuk menangkap kulit dan memutar air (Gambar 2b dan c). Kapasitas wadah pada proses ini adalah $50 \mathrm{~kg}$. Proses ini sangat berpengaruh bagi waktu produksi tempe, karena proses ini menggunakan waktu siklus yang paling lama. Ketika dilakukan dengan cara manual, proses ini menghabiskan waktu sekitar 2 jam untuk 1 kuintal kacang kedelai dengan menggunakan 2-3 tenaga kerja, sehingga dalam 1 hari kerja kedelai yang diolah hanya berkisar 4 kuintal saja. Oleh karena itu, target produksi tersebut belum bisa tercapai.

Mengingat laju produksi tempe ditentukan oleh proses pemisahan kulit dari kacangnya, maka kegiatan pengabdian masyarakat ini fokus pada pengembangan proses penyaringan kulit kacang kedelai. Proses pemisahan kulit dan kacang kedelai dengan pengadukan secara manual hanya efektif untuk jumlah yang kecil, tetapi untuk skala yang lebih besar maka harus memakai motor listrik otomatis. Dengan adanya mesin pengupas kulit ari maka tidak banyak tenaga yang diperlukan, mempercepat proses pemisahan kulit dari kacangnya, memberikan sentuhan teknologi yang tepat guna bagi masyarakat yang pada akhirnya meningkatkan produktifitas dan kualitas produk [4].

\section{SOLUSI DAN TARGET LUARAN}

Alat pengupas dan penyaring kulit ari kacang kedelai akan diupayakan untuk membantu proses pemisahan kacang dengan kulitnya. Alat tersebut dirancang untuk menggantikan tiga proses yang terdapat dalam Gambar 2 sehingga kapasitas produksi tempe dapat ditingkatkan. Alat ini dapat memisahkan kulit kacang kedelai dengan efektif tanpa sentuhan kulit manusia, sehingga kualitas kebersihan sangat terjamin.

\section{METODE PELAKSANAAN}

Sasaran kegiatan pengabdian ini adalah CV. Mitra Pangan Sejahtera yang berlokasi di Jalan Raya Cikadut, Karang Pamulang, Kota Bandung, Jawa Barat. Kegiatan ini dimulai pada bulan Oktober 2018 sampai dengan Juni 2019. Pelaksanaan kegiatan ini dilakukan dengan tahapan sebagai berikut:

\subsection{Persiapan}

Pada tahap ini dilakukan beberapa kegiatan yang akhinya akan menarik kesimpulan dasar dari pengembangan alat pemisah kulit ari kedelai. Kegiatan ini diawali dengan sosialisasi rencana Tim dengan pemilik CV. Mitra Pangan Sejahtera, kemudian dilanjutkan dengan 
studi literatur, studi lapangan dan diskusi dengan semua pekerja. Pada studi lapangan dilakukan observasi dan dijelaskan secara langsung proses pembuatan tempe sehingga dapat terlihat bagian yang dapat diperbaiki atau dikembangkan dalam proses pembuatan tempe. Pada kesempatan ini diperoleh hal-hal yang diperlukan pada tahap perancangan produk yang akan dibuat, seperti kebutuhan pengguna alat, waktu pengolahan kedelai, desain peralatan yang digunakan, dan alur pembuatan tempe.

\subsection{Perancangan Alat}

Pada tahap ini dilakukan analisis terhadap alat yang digunakan pekerja untuk memisahkan kulit ari dari kacang kedelai seperti cara kerja alat, dekomposisi struktur setiap komponen alat sehingga fungsi tiap komponen dapat ditentukan, dan merancang model alat pemisah kulit ari kacang kedelai.

4.3 Pembuatan purwa-rupa alat pemisah kulit ari kacang kedelai

Setelah perancangan alat selesai, model dibawa ke bengkel yang lokasinya tidak jauh dari pabrik tempe CV. Mitra Pangan Sejahtera untuk dibuat purwa-rupanya. Proses ini memakan waktu kurang lebih 2 bulan. Pada tahap ini terjadi beberapa perubahan rancangan alat untuk memudahkan instalasi alat di lokasi pabrik. Namun, hal ini tidak mengubah fungsi alat.

\subsection{Instalasi dan penyuluhan singkat}

Alat pemisah kulit ari kedelai yang sudah dibuat, kemudian dibawa ke lokasi pabrik tempe. Pada jadwal yang telah disepakati, pemilik dan para pekerja CV. Mitra Pangan Sejahtera dikumpulkan untuk melakukan instalasi dan ujicoba alat, serta penyuluhan singkat mengenai prosedur operasional standar, pemeliharaan, dan perbaikan mesin pada alat pengupas dan penyaring kulit ari kacang kedelai.

Berikut adalah gambaran IPTEK yang ditransfer dalam kegiatan pengabdian masyarakat ini: 


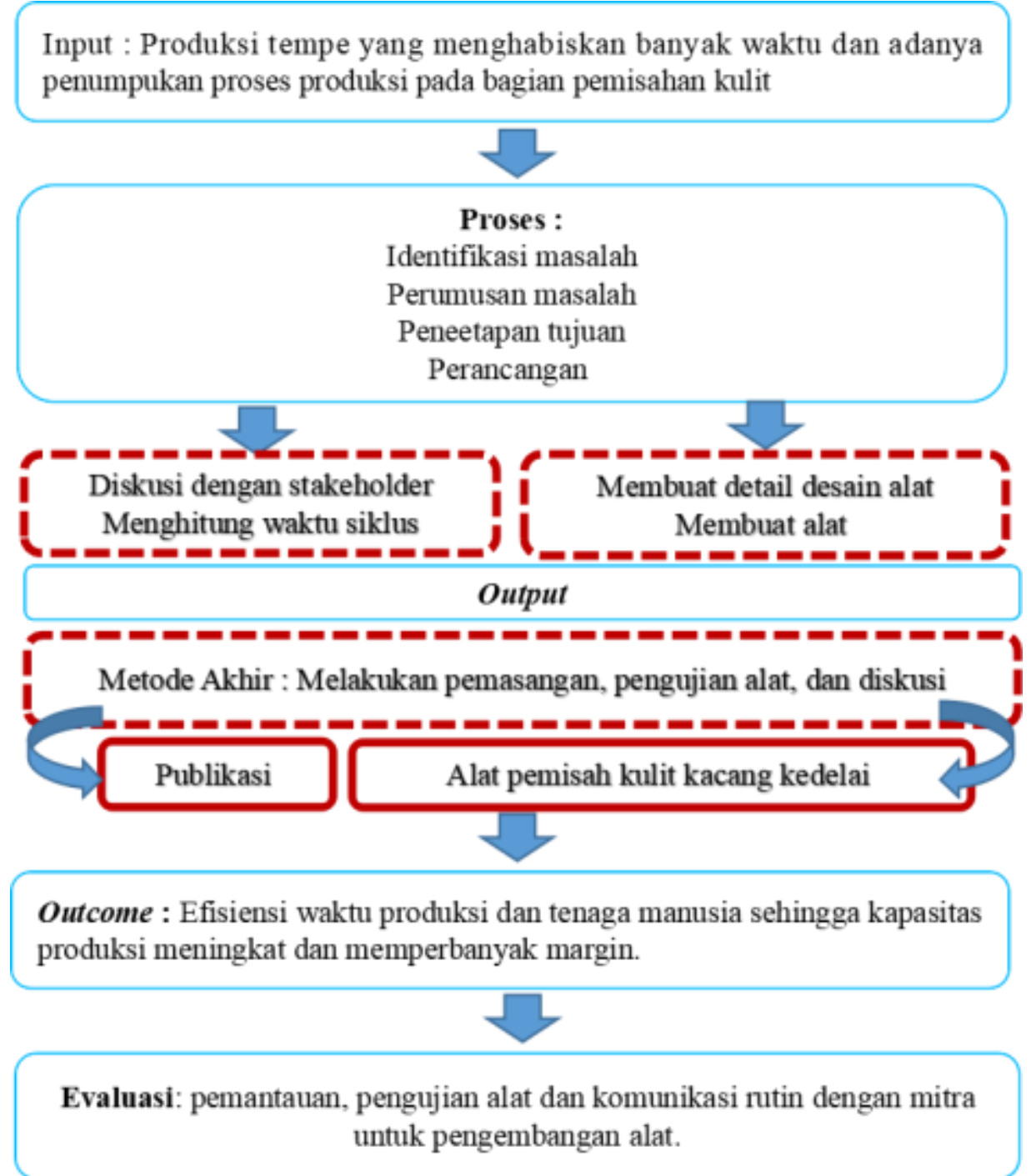

\section{HASIL DAN PEMBAHASAN}

Proses pemisahan kulit ari kedelai ini dilakukan dengan menggunakan tenaga manusia. Pada saat kacang kedelai telah masuk ke dalam wadah yang telah terisi 2/3 air dari ketinggian wadah, pekerja akan mengaduk kacang kedelai yang telah ditampung. Pekerja mengaduk kacang kedelai dengan cara meraih kulit ari kedelai yang paling dalam dengan menggunakan ayakan bambu dan menariknya ke atas. Setelah itu, pekerja memutar kacang kedelai dengan cara menaruh ayakan di permukaan air dan memutarnya dengan arah horizontal yang membuat kulit ari kedelai naik ke permukaan. Setelah kulit ari kedelai naik ke permukaan, pekerja akan menangkap kulit yang ada di permukaan dengan mengarahkan ayakan dan menggerakan ayakan mengikuti gerakan air di waktu yang sama. Kulit ari kedelai akan tertangkap oleh ayakan, sedangkan air akan jatuh kembali ke dalam wadah akibat adanya rongga-rongga kecil pada ayakan. Setelah ayakan terisi penuh oleh kulit ari kedelai, operator membuang kulit tersebut ke dalam wadah pembuangan kulit. 
Berdasarkan studi lapangan dan diskusi dengan pemilik dan para pekerja, CV. Mitra Pangan Sejahtera membutuhkan alat pemisah kulit ari kacang kedelai dengan kriteria sebagai berikut:

1. Kacang kedelai dapat teraduk tanpa bantuan pekerja.

2. Air dan kacang kedelai dapat berputar tanpa bantuan pekerja.

3. Kulit ari kedelai dan biji kacang kedelai dapat terpisah dengan gaya angkat zat cair.

4. Kulit ari kedelai dapat terbuang ke tempat pembuangan dengan alur pembuangan khusus.

Alat pemisah kulit ari kacang kedelai kemudian dirancang dimensi yang terbilang kecil dan kokoh dengan dimensi $50 \mathrm{~cm}$ x $80 \mathrm{~cm}$ x $30 \mathrm{~cm}$ dengan bobot sekitar $30 \mathrm{~kg}$ (Gambar 3). Alat ini mudah dipindahkan dan dibawa agar dapat membantu para pengusaha tempe memproduksi tempe dengan efisien dan mudah. Penjelasan mengenai bagian-bagian alat pengupas dan penyaring kulit ari kacang kedelai tersebut dapat dilihat pada Tabel 1 .

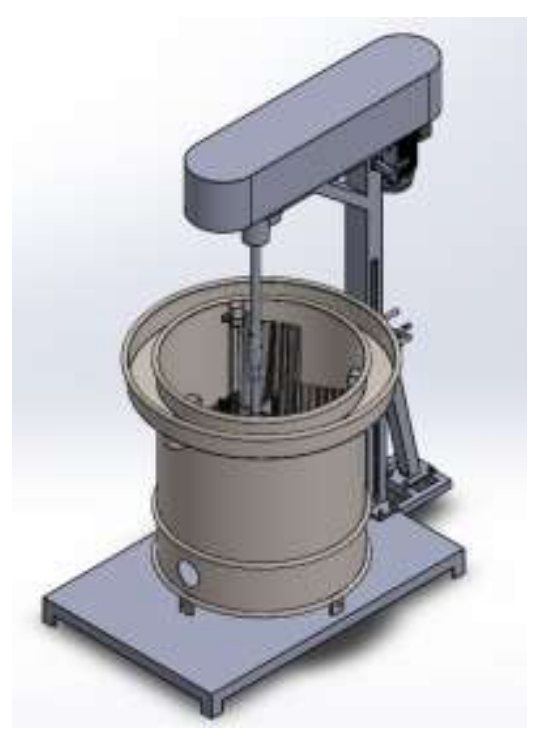

Gambar 3. Alat pengupas dan penyaring kulit ari kacang kedelai yang dibangun.

Tabel 1. Komponen alat pengupas dan penyaring kulit kacang kedelai

\begin{tabular}{|c|c|}
\hline Jenis alat & Keterangan \\
\hline motor listrik & $\begin{array}{l}\text { Motor listrik ini dapat menjadi sumber energi untuk } \\
\text { menggerakkan blade dan menghasilkan kecepatan putaran } \\
\text { blade yang konsisten. Dengan menggunakan komponen ini } \\
\text { maka proses pemisahan kulit ari kedelai dapat dilakukan } \\
\text { tanpa sepenuhnya dikerjakan oleh operator }\end{array}$ \\
\hline & $\begin{array}{l}\text { Penggunaan blade berfungsi untuk memberikan gaya putaran } \\
\text { pada air dan kacang kedelai tanpa merusak kacang kedelai }\end{array}$ \\
\hline
\end{tabular}




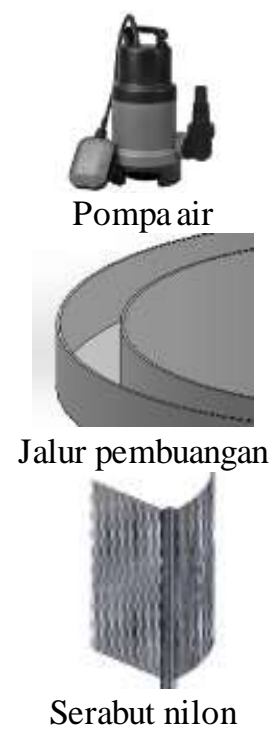

Penggunaan pompa air berfungsi untuk memberikan gaya dorong yang sesuai dan dapat mempercepat proses pemisahan kulit ari kedelai. Selain itu penggunaan pompa air juga dapat mengisi wadah penampung dengan air agar air terisi penuh oleh air

Jalur pembuangan kulit dan air hasil dari proses pemisahan kulit ari kedelai dapat membantu pemisahan kulit ari kedelai dan air. Dengan adanya jalur untuk kulit dan air maka pembuangan air dan kulit akan lebih efektif.Penggunaan jalur ini dapat mengurangi pembuangan air yang berlebihan dan dapat mengumpulkan air dan kulit dengan baik.

Putaran dari blade menyebabkan air dan kacang akan berputar searah dengan putaran. Setelah air dan kacang berputar, kulit dan kacang akan dengan mudah berpisah dengan bantuan serabut nilon yang ditempatkan statis di dinding tabung. Penambahan serabut nilon juga dapat memastikan bahwa seluruh kacang yang ada di dalam tabung akan berpisah dengan kulitnya.

Instalasi alat dilakukan disiang hari dengan bantuan para pekerja CV. Mitra Pangan Sejahtera (Gambar 4a-c). Kegiatan ini dilanjutkan dengan ujicoba alat yang pemisah kulit ari yang telah dibuat (Gambar 4d). Alat ini mampu memisahkan kulit kacang kedelai dengan cepat, kuantitas pemisahan kacang kedelai hingga mencapai $200 \mathrm{~kg}$ dalam waktu 30 menit. Secara keseluruhan, alat ini dapat mengurangi waktu produksi tempe dan menjamin kualitas kebersihan tempe.

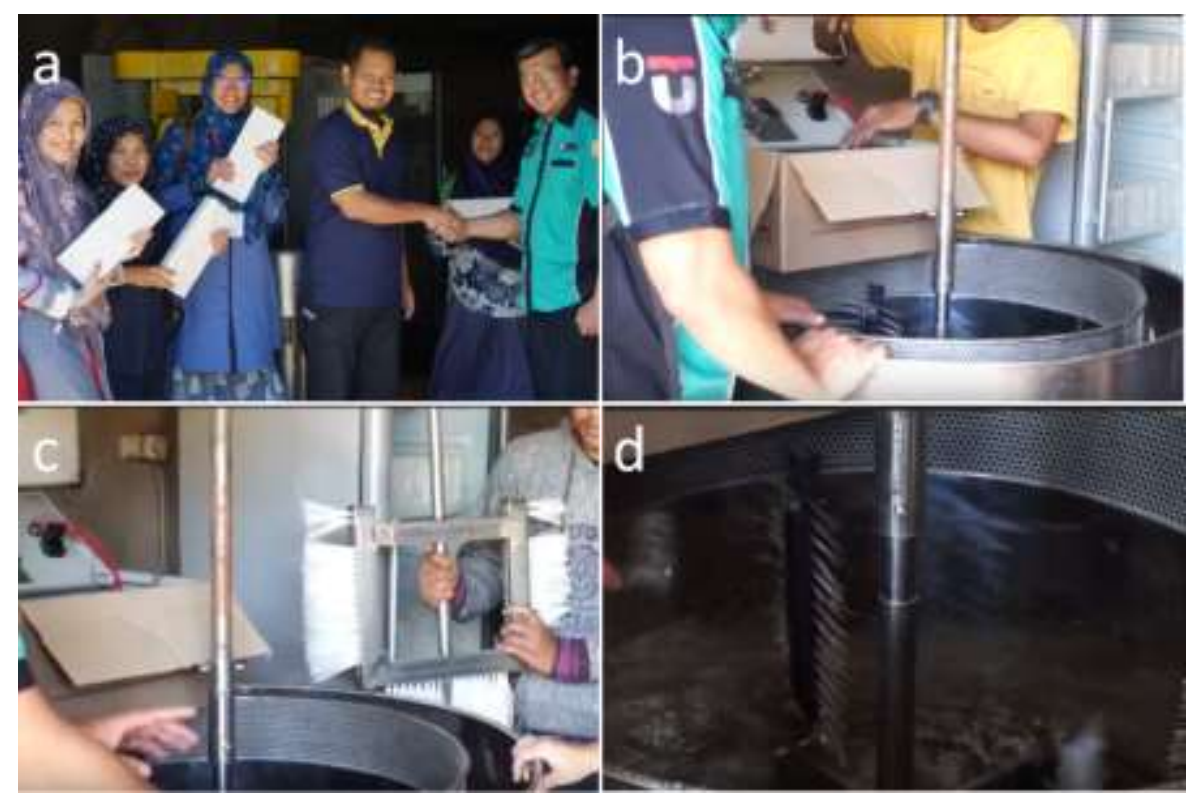

Gambar 4. (a) Serah terimaalat pengupas dan penyaring kulit ari kacang kedelai kepada pemilik CV. Mitra Pangan Sejahtera, (b,c) Instalasi alat, (d) Uji coba pengaduk alat pemisah kulit ari kacang kedelai.

\section{KESIMPULAN DAN SARAN}

Penerapan teknologi yang dikembangkan oleh universitas untuk masyarakat harus terus dikembangkan sesuai dengan perkembangan ilmu pengetahuan dan memiliki sifat tepat guna. Masyarakat harus diperkenalkan dengan berbagai teknologi tepat guna yang dapat mempermudah kegiatan mereka sehari-hari. CV. Mitra Pangan 
Sejahtera merupakan salah satu UMKM di Kota Bandung dengan potensi usaha yang baik, dengan kapasitas produksi tempe yang melebihi 1 kuintal per hari. Kapasitas produksi ini harus terus ditingkatkan karena permintaan tempe yang melebihi kemampuan produksi UMKM tersebut. Alat pengupas dan pemisah kulit ari kacang kedelai yang dirancang sesuai dengan kebutuhan mitra diharapkan dapat membantu mitra untuk mencapai target tersebut. Rekomendasi untuk kegiatan selanjutnya adalah pengembangan alat pengupas dan penyaring kulit kacang yang sudah ada dan pengembangan tahapan lain dalam proses produksi tempe seperti proses peragian, sehingga waktu produksi dan efisiensi dapat ditingkatkan.

\section{DAFTAR PUSTAKA}

[1] Badan Pusat Statistik, "Rata-rata Konsumsi per Kapita Seminggu Beberapa Macam Bahan Makanan Penting, 2007 - 2017”, 2018. [Online]. Available: https://www.bps.go.id/statictable/2014/09/08/950/rata-rata-konsumsi-perkapita-seminggu-beberapa-macam-bahan-makanan-penting-20072017.html. [Diakses 24 Juni 2019].

[2] PUSIDO Badan Standardisasi Nasional, "Tempe: Persembahan Indonesia untuk Dunia", 2012. Jakarta. Badan Standardisasi Nasional

[3] Suprapti, L. M., "Teknologi Pengolahan Pangan: Pembuatan Tempe”, 2003. Yogyakarta, Penerbit Kanisius

[4] Sutejo, A., dan Prayoga, A. R., "Rancang Bangun Alat Pengupas Kulit Ari Kacang tanah (Arachis hypogaea) Tipe Engkol", 2012, Jurnal Keteknikan Pertanian, Vol. 26, No. 2, 107 - 114. 